\title{
VARIABILITY OF SOME MECHANICAL PROPERTIES OF SAN RAMON TALL VARIETY OF COCONUT
}

by

\author{
R. N. Palomar*
}

\begin{abstract}
The natural variation of some strength properties of about 80-year old brown-and green-pigmented San Ramon variety of coconut was investigated. The properties were determined from tests on small clear specimens in the air dry condition with an average moisture content of $16.98 \%$. The mechanical properties studied include modulus of rupture, stress at elastic limit and modulus of elasticity in static bending, maximum crushing strength in compression parallel to grain, stress at elastic limit and in compression perpendicular to grain, and shear parallel to grain.

The brown-pigmented trees showed significantly higher values in all the mechanical properties than the green-pigmented palms.

For the brown-and green-pigmented trees, the values of strength properties markedly decreased with increasing height levels and significantly increased radially from the core to the periphery of the stem.
\end{abstract}

\section{INTRODUCTION}

The coconut is an important tropical crop belonging to the palm family. It is found to grow well between $20 \mathrm{ON}$ and $20 \mathrm{OS}$ of the equator and in altitude below 600 meters. It is a source of foreign revenues and used as food ingredient in many Asian countries.

The coconut industry in the Philippines, which supports about one-third of its population, is characterized by low productivity. This is due, among others, to poor quality of planting materials, low level of cultural management and increasing proportions of old and unproductive palms.

Currently, the total coconut area is estimated at 3.42 million hectares. About $30 \%$ of this area have reached Benility and they consist mainly of palms that are 60 years old and over. At an average log volume of 95 cubic meters per hectare, around 97.47 million cubic meters of coconut trunks are readily available for economic utilization.

In the past, the wood industry depended solely on conventional wood as source of raw materials for housing, furniture and other finished wood products. As a result of the heavy reliance on the traditional wood species, the industry faces a problem brought about by the scarcity and prohibitive cost of conventional wood.

There is, therefore, an urgent need to look for indigenous wood materials that could substitute commercially-known wood species to overcome the inadequate supply of timber and at the same time help conserve our remaining forest resources. one material that is locally available in may parts of the country is the coconut trunk.

*Chief, Coconut Timber Utilization, Philippine Coconut Authority, Philippines. 
The growing number of old and senile palms requires the launching of a large-scale replanting program. Based on the above estimate, around 100 million unproductive coconut palm shall be replanted. On the basis of sawn lumber recovery of 0.25 cubic meter per tree, a total of 25 million cubic meters of cocolumber would be available for economic utilization in the first ten years of replanting. In a 40-year cycle replanting program, an annual supply of about 8.5 million trees representing 2.125 million cubic meters of sawn timber would be recovered.

When old palms are felled, proper disposal of the trunks should be done. Otherwise, if they are allowed to rot in the f ield, they would serve as breeding places of rhinoceros beetles which would ultimately create serious infestation problem to the newlyestablished plantation. As a result, it has been recognized that the most effective and proper way of disposing the felled trunks is to convert them to saleable finished wood products. This method would not only provide proper disposal of felled trunks at replanting time but would also generate employment and give additional source of income to farmers of coconut producing regions. Furthermore, cocowood utilization would supplement the supply of materials for the wood processing industry and eventually would provide lowcost housing construction materials for the shelter program of the government.

This investigation was done to determine the variability of some mechanical properties of coconut stem such as static bending (modulus of rupture, stress at elastic limit and modulus of elasticity), compression parallel and perpendicular to grain, and shear parallel to grain. This study was conducted at the Department of Wood Science and Technology, College of Forestry, UPLB during summer, 1993.

\section{MATERIALS AND METHODS}

Two (2) coconut stems representing the brown-and green-pigmented San Roman tall coconut variety were collected from the Philippine Coconut Authority's Zamboanga Research Center (PCA-ZRC) plantation located in San Ramon, Zamboanga City. The palms were about 80 years old with average butt and top diameters of 35 centimeters and height of 20 meters.

The sampling technique employed is shown in Fig.l. Four (4) bolts, each 2.0 meters long, representing four (4) height levels of the stem were cut and used in this study. The height levels consisted of 5\% (LI), 25\% (U), 45\% (L3) and 65\% (L4) of the total height starting from the butt portion of the stem.

In each bolt, the core (S1), sub-dermal (S2) and dermal (S3) portions representing the soft, medium and hard segments of cocowood were determined and marked as shown in Fig. la. The round method of sawings was employed to segregate the three (3) radian segments of cocowood. The bolts were sawn into flitches which were air dried for one month prior to resawing to final dimensions of the various specimens.

All specimens were prepared and machined at the PCA-ZRC workshop and then shipped to the WST Department for testing.

Preparation of specimens and testing methods for mechanical properties were adopted from the American Society for Testing and Materials Designation D 143-52 (Revised 1972): Standard methods of testing small clear specimens of timber. The mean moisture content of the wood samples at the time of testing was $16.98 \%$.

The data collected were statistically analyzed using the Completely Randomized Design with subsampling. The data were processed in a PC microcomputer to ensure accurate results. Comparisons among treatment means were made employing the Duncan's Multiple Range Test (DMRT). 


\section{RESULTS AND DISCUSSION}

The analysis of variance on modulus of rupture (MOR), stress at elastic limit (SEL), and modulus of elasticity (MOE) in static bending, maximum crushing strength in compression parallel to grain $(\mathrm{C} \backslash \mathrm{G})$, stress at elastic limit in compression perpendicular to grain $(\mathrm{C} \mathrm{G})$ and shear parallel to grain $(S \backslash \backslash)$ is presented in Table 1.

A high degree of significance was observed in all the strength properties between and within trees $(\mathrm{T})$. Within trees, the mechanical properties markedly varied between height levels $(\mathrm{L})$ as well as radial portions or segments $(\mathrm{S})$.

Significant interaction effect of $\mathrm{T} x \mathrm{~L}$ was noted as far as maximum crushing strength in $\mathrm{C} \backslash \mathrm{G}$ and stress at elastic limit in $\mathrm{C} \mathrm{G}$ are concerned. Likewise, highly significant interaction effect of $\mathrm{T} \times \mathrm{S}$ was observed in all the strength properties except S\IGIn addition, interaction effect of $\mathrm{L} \times \mathrm{S}$ was highly significant only in SEL in static bending and stress at elastic limit in C G. On the other hand, interaction effect of TxLxS was significant in MOE in static bending, maximum crushing strength in C\\G, stress at elastic limit in CLG and S\\G.

Table 2 shows the main effects of $\mathrm{T}, \mathrm{L}$ and $\mathrm{S}$ on the strength properties of cocowood.

Highly significant variations in the strength properties between trees were noted except SEL in static bending. Result showed that the brown-pigmented trees ( $\mathrm{Tl}$ ) had markedly higher mechanical properties than the green-pigmented trees.

Variations in the mechanical properties between height levels were likewise observed. All properties significantly decreased with increasing height levels within the tree. The values of strength properties were highest at the butt portion and lowest at the top section of the stem.

Differences in strength properties were significant between radial segments. All properties increased from the core to the peripheral (dermal) section of the trunk.

In terms of anatomical features (Palomar, 1993) the fiber diameter decreased with increasing height levels and also it decreased from the center to the periphery in the radial direction. The cellwall thickness decreased with increasing height levels but it increased radially from the core to the outer section of the stem. This clearly showed that the amount of wood substance varied significantly with height levels and also from the center to the outside portion of the trunk. The amount of wood substance indicates the amount of fibrous cells and the thickness of their walls which are needed to show the mechanical properties of wood. Thus, the greater the amount of cellwall substance, the higher is the mechanical properties of the coconut stem.

The effect of $\mathrm{T} x \mathrm{~L}$ on the strength properties of cocowood is presented in Table 3. Insignificant interaction effect of $\mathrm{T} \times \mathrm{L}$ waB observed on static bending and S\G. On the other hand, maximum crushing strength in Cl|G and stress at elastic limit in $\mathrm{C} G$ were significantly influenced by the interaction of $\mathrm{T} x \mathrm{~L}$. Both properties were highest on specimens taken $\mathrm{f}$ rom the brown-pigmented trees located at the butt portion of the trunk (Tl x LI) and lowest on samples from green-pigmented trees taken from the top portion of the stem (T2 x L4).

Table 4 shows the interaction effect of $\mathrm{T} \times \mathrm{S}$ on the properties of cocowood. The effect of $\mathrm{T} \times \mathrm{S}$ on the static bending, maximum crushing strength in CllG and stress at elastic limit in C G was highly significant. The peripheral portion of brown-pigmented trees (TlxS3) showed the highest strength properties followed by the peripheral segment of green-pigmented trees (T2 x S3). However, the S\\G 
was not markedly affected by the interaction of $\mathrm{T} \times \mathrm{S}$. The lowest strength properties were taken from the core of green-pigmented trees (T2xSl).

The interaction effect of LxS showed no significant difference on MOR and MOE in static bending, maximum crushing strength in C $\backslash \mathrm{G}$ and $S \backslash \mathrm{G}$ (Table 5). However, highly significant effect of $\mathrm{L} \times \mathrm{S}$ was noted on SEL in static bending and stress at elastic limit in $\mathrm{C} \mathrm{G}$. The peripheral butt portion (LlxS3) of the stem distinctly revealed the highest values for all the strength properties followed in descending order by L2xS3, L3xS3 and L4xS3. The core (SI) and the sub-dermal (S2) segments at any height levels generally exhibited inferior strength properties compared to the peripheral or dermal portions. The lowest values were taken from the core top portion of the stem (L4xSl).

Table 6 reflects the interaction effect of TxLxS on the strength properties of cocowood. In terms of MOE in static bending, the highest mean value of 6,640 MPa was obtained from the dermal butt portion of the brown-pigmented trees (TlxLlxS3) which was significantly different from the dermal butt section of the green-pigmented trees $(\mathrm{T} 2 \times \mathrm{xL} 1 \mathrm{xS} 3)$ with an average value of 5,230 MPa. However, the value of T2xLlxS3 was not significantly different from the values of TlxL2xS3 $(5,250$ $\mathrm{MPa}$ ) and TlxL3xS3 (5,110 MPa). This was followed by T2xL2xS3 with a value of 4,360 MPa which was insignificantly different from T2xL3xS3 of 4,250 MPa. The lowest value of $830 \mathrm{MPa}$ was taken from T2xL4xSl which was not significantly different from TlxL4xS1 with a value of $890 \mathrm{MPa}$.

The highest mean value for maximum crushing strength in CllG was noted on TlxLlxS3 of 31.44 MPa which was markedly different from TlxL2xS3 of $28.47 \mathrm{MPa}$ followed significantly in descending order by T2xLlxS3 of $23.74 \mathrm{MPa}$ and T2xL2xS3 of $20.48 \mathrm{MPa}$. In contrast, the lowest value was observed on $\mathrm{T} 2 \mathrm{xL} 4 \mathrm{xS} 1$ of $3.89 \mathrm{MPa}$ which was insignificantly different from TlxL4xS1 of 3.98 MPa. The same trend was noted on stress at elastic limit in C G wherein the highest and lowest values were obtain from TlxLlxS3 and T2xL4xS1 of $18.85 \mathrm{MPa}$ and $0.96 \mathrm{MPa}$, respectively.

In $S \backslash \backslash G$, the best treatment combination was observed on TlxLlxS3 of 5.71 MPa. This was followed by TlxL2xS3 of 4.94 MPa and TlxL3xS3 of 4.81 MPa. Result of this particular test revealed that the brown-pigmented trees are superior than the green-pigmented trees in terms of S\\G.

\section{CONCLUSIONS}

Overall result of this investigation clearly Bhowed that the mechanical properties of the coconut tem varied widely between and within trees.

The values of strength properties of brown-pigmented trees were generally higher than the green pigmented trees wherein both palms belong to San Ramon tall variety of coconut.

At any height levels within the stem, the values of strength properties at the periphery (dermal section) were significantly higher than at the center (core). The values of strength properties tended to increase with increasing height levels but thiB was dependent on the radial position of the specimens.

Based on the result of thiS Btudy, it is concluded that the peripheral portion of the stem which has relatively high strength properties is the important and valuable material to recover during the sawmilling of coconut trunks. This material can be used for load bearing structures particularly on low-cost house construction. 


\section{REFERENCES}

AMERICAN SOCIETY FOR TESTING AND MATERIALS. 1972. Standard methods of testing small clear specimens of timber. ASTM Designation D143-52.

ESPILOY, Z. B. AND M. M. MARUZZO. 1986. Variability of frequency of fibrovascular bundles in some Philippine palms. The Philippine Lumberman. 32(5): 26-31.

PALOMAR, R. N. 1993. Variability of some cocowood quality indicators. A research paper submitted in partial fulfillment of the requirements of WST 201 (Tree Growth and Wood Quality) under Dr. Wilfredo M. America, Professorial Lecturer of Wood Science and Technology, College of Forestry, UPLB, College, Laguna, Second Semester 1992-1993.

PALOMAR, R. N. AND J. 0. SIOPONGCO 1988. Technology manual on cocowood as construction materials. Published by UNDP/UNIDO Regional Network in AsiaPacific for Low-Cost Building Materials Technologies and Construction Systems.

ROJO, J. P., F. O. TESORO, S. K. S. LOPEZ AND M. E. DY. 1988. Coconut wood utilization research and development. The Philippine experience. A publication of FPRDI and IDRC of Canada.

TOMLINSON, P. B. 1961. Anatomy of the monocotyledons II. Palmae Oxford University Press. Amen House, London E. C. 4.

\section{ACKNOWLEDGEMENT}

The author is deeply grateful to Dean Virgilio A. Fernandez who provided expert guidance in the course of the study.

Special thanks is expressed to Engr. Teodulfo S. Delgado, Engineer II, Department of Wood Science and Technology for testing the majority of the cocowood specimens, and to Dr. Marina Alipon, Senior Science Research Specialist, Forest Products Research and Development Institute for testing the samples on stress at elastic limit in compression perpendicular to grain.

Likewise, special acknowledgememt is extended to Mr. Leon M. Alforja, Division Chief III, Philippine Coconut Authority (PCA) for his technical expertise in processing and statistical analysis of

the data and to my colleagues at PCA-Zamboanga Center who in countless small ways helped materialize this investigation. 


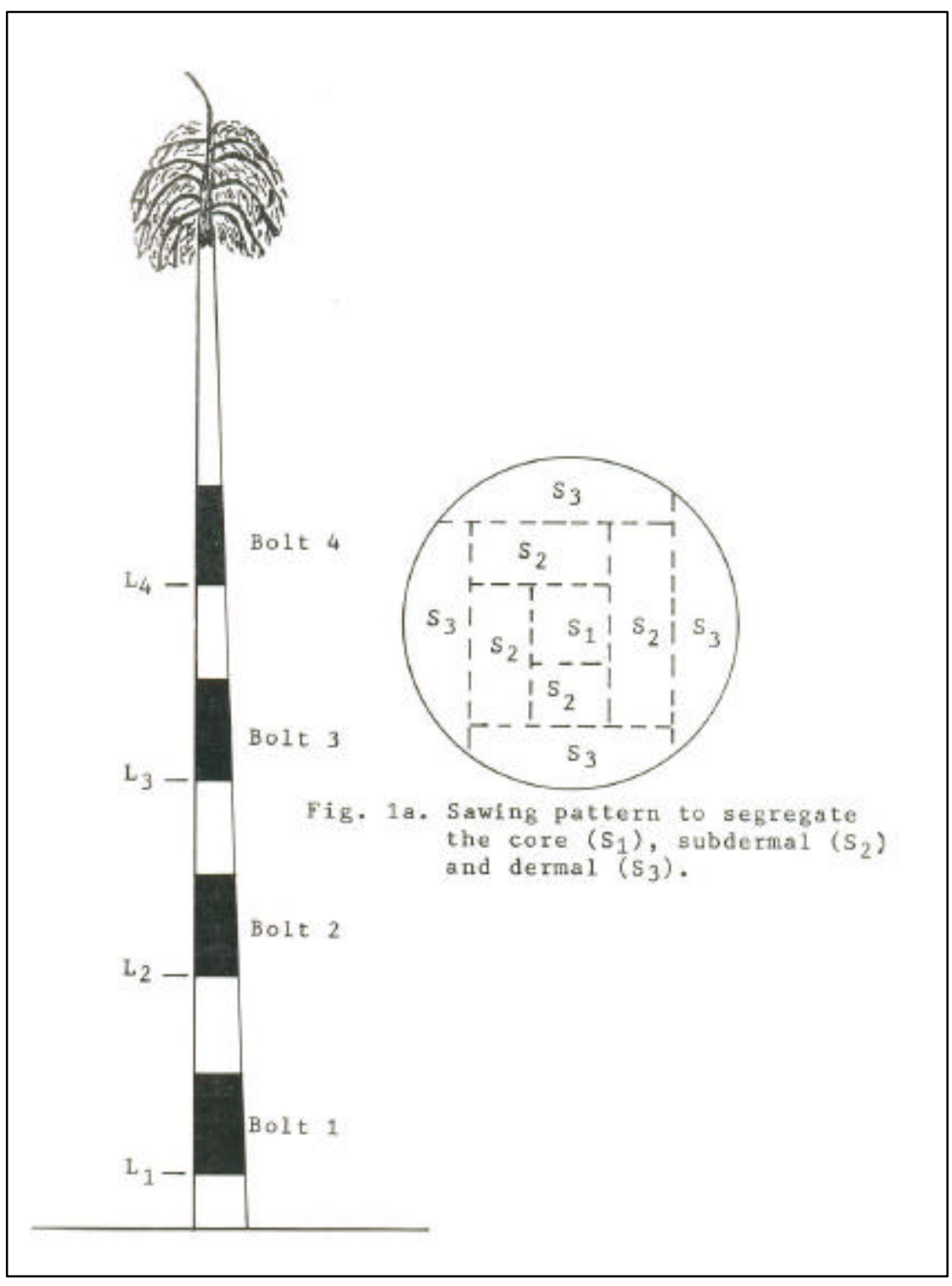

Fig. 1. Sampling technique used in the study 
Table 1 Analysis of variance on mechanical properties (static bending (modulus of rupture (MCR), Street at elastic limit (SEL), and modulus of leasticity (Moe); compression perndicular to Grain (c//G); compression parallel to grain $(\mathrm{C} \mathrm{G})$; and shear parallele to grain $(\mathrm{S} / / \mathrm{G})$

Of coconut wood

\begin{tabular}{|c|c|c|c|c|c|c|c|}
\hline \multicolumn{8}{|c|}{ Mean Square } \\
\hline \multirow{2}{*}{$\begin{array}{l}\text { Source of } \\
\text { Variation }\end{array}$} & d.f. & \multicolumn{2}{|c|}{ Static Bending } & \multirow[b]{2}{*}{$\begin{array}{c}\text { MOE } \\
(\times 1000 \mathrm{Mpa})\end{array}$} & \multirow[b]{2}{*}{$\begin{array}{l}\mathrm{C} / / \mathrm{G} \\
(\mathrm{Mpa})\end{array}$} & \multirow[b]{2}{*}{$\begin{array}{c}\text { C G } \\
\text { (Mpa) }\end{array}$} & \multirow[b]{2}{*}{$\begin{array}{c}\mathrm{S} / / \mathrm{G} \\
\text { (Mpa) }\end{array}$} \\
\hline & & $\begin{array}{l}\text { MCR } \\
\text { (Mpa) }\end{array}$ & $\begin{array}{c}\text { SEL } \\
\text { (Mpa) }\end{array}$ & & & & \\
\hline Total & 71 & & & & & & \\
\hline Trees $(\mathrm{T})$ & 1 & $42.8738^{*}$ & $9.2737 n s$ & $1.9241^{\star *}$ & $57.4413^{\star \star}$ & $69.2468 * *$ & $13.7570^{\star *}$ \\
\hline Height (L) & 3 & $467.8914^{*}$ & $186.3832^{\star \star}$ & $5.5324^{\star \star}$ & $153.3856^{*}$ & $60.6547^{*}$ & $3.6348^{*}$ \\
\hline $\mathrm{T} \times \mathrm{L}$ & 3 & $13.0817 n s$ & $1.1662 \mathrm{~ns}$ & $0.0784 \mathrm{~ns}$ & $14.9363^{\star *}$ & $3.2735^{\star}$ & $0.2667 \mathrm{~ns}$ \\
\hline Radius ${ }^{\circledR} / \mathrm{L} / \mathrm{T}$ & 16 & 7.8715 & 3.6017 & 0.0924 & 1.0677 & 0.6548 & 0.1507 \\
\hline Segment (S) & 2 & 4191.6962 ** & $2291.7091^{*}$ & $69.7133^{*}$ & $1578.0694^{* *}$ & 697.6242 & $48.9792^{\star \star}$ \\
\hline $\mathrm{T} \times \mathrm{S}$ & 2 & $39.0455^{\star}$ & $27.8812^{\star \star}$ & 1.7269 ** & $21.0438^{\star *}$ & $18.1668^{\star *}$ & $0.1751 \mathrm{~ns}$ \\
\hline $\mathrm{L} \times \mathrm{S}$ & 6 & 48.6777ns & $19.3506^{\star \star}$ & $0.7855 \mathrm{~ns}$ & 15.1793ns & 18.5780 ** & $0.3237 \mathrm{~ns}$ \\
\hline$T \times L \times S$ & 6 & $14.1418 n s$ & $1.4843 n s$ & $0.2256^{*}$ & $8.3620^{\star *}$ & $2.1312^{\star *}$ & $0.3844^{*}$ \\
\hline Residual (E) & 32 & 6.6444 & 2.0176 & 0.0733 & 1.1800 & 0.4103 & 0.1333 \\
\hline Grand Mean & & 24.20 & 16.62 & 2.99 & 13.68 & 6.31 & 3.10 \\
\hline Std. Error & & & & & & & \\
\hline T-mean & & 0.468 & 0.316 & 0.051 & 0.172 & 0.135 & 0.065 \\
\hline L-mean & & 0.853 & 0.255 & 0.066 & 0.911 & 0.426 & 0.122 \\
\hline S-mean & & 1.275 & 1.078 & 0.268 & 0.936 & 0.870 & 0.085 \\
\hline TXL-mean & & 0.935 & 0.633 & 0.101 & 0.344 & 0.270 & 0.129 \\
\hline TxS-mean & & 0.744 & 0.410 & 0.080 & 0.314 & 1.185 & 0.105 \\
\hline LxS-mean & & 1.535 & 0.497 & 0.194 & 1.181 & 0.596 & 0.253 \\
\hline TxLxS-mean & & 1.488 & 0.820 & 0.161 & 0.627 & 0.370 & 0.211 \\
\hline C.V. residual (\%) & & 10.7 & 8.5 & 9.3 & 7.9 & 10.2 & 11.8 \\
\hline
\end{tabular}

ns - Not significant

* - Significant at $5 \%$ level

** - Highly significant at $1 \%$ level 
Table 2 Main effects of sampling areas on the chemical properties (static) bending (modulus of Rupture (MCR), tress at elastic limit (SEL), and modulus of elasticity (MOE); compression Perpendicular to grain $(\mathrm{C} / / \mathrm{G})$; compression parallel to grain $(\mathrm{C} \mathrm{G})$; and shear parallel to Grain (S//G) of coconut wood

\begin{tabular}{|c|c|c|c|c|c|c|}
\hline \multicolumn{7}{|l|}{ Sampling Area } \\
\hline & $\begin{array}{l}\mathrm{MCR} \\
(\mathrm{MPa})\end{array}$ & $\begin{array}{c}\text { SEL } \\
(\mathrm{MPa})\end{array}$ & $\begin{array}{c}\text { MOE } \\
(x 1000(\mathrm{MPa})\end{array}$ & $\begin{array}{c}\mathrm{C} / / \mathrm{G} \\
(\mathrm{MPa})\end{array}$ & $\begin{array}{l}\mathrm{C} \mathrm{G} \\
(\mathrm{MPa})\end{array}$ & $\begin{array}{l}\mathrm{S} / / \mathrm{G} \\
(\mathrm{MPa})\end{array}$ \\
\hline \multicolumn{7}{|l|}{ Tree $(\mathrm{T})$} \\
\hline $\mathrm{T} 1$ & $24.99 a$ & 19.98 & $3.15 \mathrm{a}$ & $14.57 \mathrm{a}$ & $7.29 \mathrm{a}$ & $3.54 \mathrm{a}$ \\
\hline $\mathrm{T} 2$ & $23.43 b$ & 16.26 & $2.82 \mathrm{~b}$ & $12.79 b$ & $5.33 b$ & $2.67 \mathrm{~b}$ \\
\hline \multicolumn{7}{|l|}{ Statistical } \\
\hline Significance & $*$ & NS & $* *$ & $* *$ & $* *$ & ** \\
\hline S.E. (T-mean) & 0.468 & 0.316 & 0.051 & 0.172 & 0.135 & 0.065 \\
\hline \multicolumn{7}{|l|}{ Height Levels (L) } \\
\hline L1 & $30.22 \mathrm{a}$ & $23.37 \mathrm{a}$ & $3.65 \mathrm{a}$ & $17.10 \mathrm{a}$ & $8.36 \mathrm{a}$ & $3.62 \mathrm{a}$ \\
\hline L2 & $25.93 \mathrm{ab}$ & $17,75 b$ & $3.11 \mathrm{ab}$ & $14.93 \mathrm{ab}$ & $7.15 \mathrm{ab}$ & $3.28 \mathrm{ab}$ \\
\hline L3 & $22.24 b$ & $15.57 \mathrm{c}$ & $2.88 b c$ & $12.19 b c$ & $5.58 b c$ & $2.92 b c$ \\
\hline L4 & $18.32 \mathrm{bc}$ & $12.79 d$ & $2.31 \mathrm{c}$ & $10.50 \mathrm{c}$ & $4.15 \mathrm{c}$ & $2.58 \mathrm{c}$ \\
\hline \multicolumn{7}{|l|}{ Statistical } \\
\hline Significance & $* *$ & $* *$ & ** & * & $*$ & $*$ \\
\hline S.E. (L-mean) & 0.853 & 0.255 & 0.066 & 0.911 & 0.426 & 0.122 \\
\hline \multicolumn{7}{|l|}{ Segment (S) } \\
\hline $\mathrm{S} 1$ & $11.56 \mathrm{c}$ & $7.48 \mathrm{c}$ & $1.36 \mathrm{c}$ & $6.01 \mathrm{c}$ & $1.85 \mathrm{c}$ & $1.65 c$ \\
\hline S2 & $23.12 b$ & $15.48 \mathrm{~b}$ & $2.84 \mathrm{~b}$ & $12.88 \mathrm{~b}$ & $4.79 b$ & $3.16 \mathrm{~b}$ \\
\hline S3 & $37.93 b$ & $26.92 a$ & $4.76 \mathrm{a}$ & $22.16 \mathrm{a}$ & $12.30 \mathrm{a}$ & $4.51 \mathrm{a}$ \\
\hline \multicolumn{7}{|l|}{ Statistical } \\
\hline Significance & $* *$ & * & * & ** & $*$ & $* *$ \\
\hline S.E. (S-mean) & 1.275 & 1.078 & 0.268 & 0.936 & 0.870 & 0.085 \\
\hline Grand Mean & 24.20 & 16.62 & 2.99 & 13.68 & 6.31 & 3.10 \\
\hline
\end{tabular}

1/ Mean under each column heading in each sampling ara having the same letter(s) are not significantly different at $5 \%$ level (DMRT)

NS - Not significant

* - siginificant at $5 \%$ level

** - Highly signifianct at $1 \%$ level 
Table 3

Interaction effects of tree $(\mathrm{T})$ be height levels (L) of sampling areas on the mechanical Properties (static bending (modulus of rupture (MOR), stress at bending (modulus of rupture

(MOR), stress at elastic limit (SEL), and modulus of elasticity (MOE); compression perpendicular to grain $(\mathrm{C} / / \mathrm{G})$; compression parallel to grain $(\mathrm{C} \mathrm{G})$; and shear parallel to grain $(\mathrm{S} / / \mathrm{G})$ of coconut wood

\begin{tabular}{|l|c|r|r|r|r|r|r|}
\hline \multicolumn{4}{|c|}{ Sampling Area } & \multicolumn{4}{|c|}{ Static Beding } \\
\hline \multicolumn{1}{|c|}{$\begin{array}{c}\text { Tree } \\
(\mathrm{T})\end{array}$} & $\begin{array}{c}\text { Height } \\
\text { (L) }\end{array}$ & $\begin{array}{c}\text { MOR } \\
\text { (Mpa) }\end{array}$ & $\begin{array}{c}\text { SEL } \\
\text { (Mpa) }\end{array}$ & $\begin{array}{c}\text { MOE } \\
(\mathrm{x} 1000 \mathrm{Mpa})\end{array}$ & $\begin{array}{c}\text { C//G } \\
(\mathrm{Mpa})\end{array}$ & $\begin{array}{c}\text { C G } \\
(\mathrm{Mpa})\end{array}$ & $\begin{array}{c}\text { S//G } \\
(\mathrm{Mpa})\end{array}$ \\
\hline T1 & L1 & 31.65 & 20.53 & 3.80 & $18.67 \mathrm{a}$ & $9.47 \mathrm{a}$ & 4.20 \\
& L2 & 27.60 & 18.44 & 3.36 & $16.70 \mathrm{~b}$ & $8.63 \mathrm{~b}$ & 3.78 \\
& L3 & 22.33 & 16.00 & 3.04 & $12.45 \mathrm{c}$ & $6.47 \mathrm{dc}$ & 3.27 \\
& L4 & 18.30 & 12.95 & 2.40 & $10.48 \mathrm{~d}$ & $4.60 \mathrm{a}$ & 2.91 \\
& & & & & & & \\
\hline T2 & L1 & 28.77 & 20.21 & 3.49 & $15.53 \mathrm{~b}$ & $7.26 \mathrm{c}$ & 3.04 \\
& L2 & 24.46 & 17.06 & 2.86 & $13.59 \mathrm{c}$ & $5.68 \mathrm{~d}$ & 2.79 \\
& L3 & 22.16 & 15.15 & 2.72 & $11.94 \mathrm{~cd}$ & $4.69 \mathrm{e}$ & 2.58 \\
& L4 & 18.33 & 12.63 & 2.22 & $10.52 \mathrm{~d}$ & $3.70 \mathrm{f}$ & 2.25 \\
\hline Statistical & NS & NS & NS & $* *$ & & & NS \\
Significance & & & & & & & \\
Grand Mean & 24.20 & 16.62 & 2.99 & 13.68 & 6.31 & 6.31 & 3.10 \\
S.E. (S-mean) & 0.935 & 0.633 & 0.101 & 0.344 & 0.270 & 0.270 & 0.129 \\
\hline
\end{tabular}

1/ Mean under each column heading having the same letter(s) are not significantly different at 5\% level (DMRT)

NS - Not significant

* - Significant at $5 \%$ level

** - Highly significant at $1 \%$ level 
Table 4

Interaction effects of tree $(\mathrm{T})$ by segments $(\mathrm{S})$ of sampling areas on the mechanical Properties (static bending modulus of rupture (MOR), stress at bending (modulus of rupture (MOR), stress at elastic limit (SEL), and modulus of elasticity (MOE); compression perpendicular to grain $\{\mathrm{C} / / \mathrm{G}\}$; compression parallel to grain $(\mathrm{C} \mathrm{G})$; and shear parallel to grain $(\mathrm{S} / / \mathrm{G})$ of coconut wood

\begin{tabular}{|l|c|c|c|c|c|c|c|}
\hline \multicolumn{4}{|c|}{ Sampling Area } & \multicolumn{3}{c|}{ Static Bending } & \\
\hline \multicolumn{1}{|c|}{$\begin{array}{c}\text { Tree } \\
(\mathrm{T})\end{array}$} & $\begin{array}{c}\text { Segment } \\
(\mathrm{S})\end{array}$ & $\begin{array}{c}(\mathrm{MOR}) \\
(\mathrm{MPa})\end{array}$ & $\begin{array}{c}\text { SEL } \\
(\mathrm{MPa})\end{array}$ & $\begin{array}{c}\text { MOE } \\
(\mathrm{x} 1000(\mathrm{MPa})\end{array}$ & $\begin{array}{c}\mathrm{C} / / \mathrm{G} \\
(\mathrm{MPa})\end{array}$ & $\begin{array}{c}\mathrm{C} \text { G } \\
(\mathrm{MPa})\end{array}$ & $\mathrm{S} / / \mathrm{G}$ \\
\hline $\mathrm{T} 1$ & $\mathrm{~S} 1$ & $13.22 \mathrm{c}$ & $8.18 \mathrm{e}$ & $1.50 \mathrm{~d}$ & $6.44 \mathrm{~d}$ & $2.15 \mathrm{e}$ & 2.05 \\
& $\mathrm{~S} 2$ & $22.43 \mathrm{~b}$ & $14.53 \mathrm{~d}$ & $2.74 \mathrm{c}$ & $12.15 \mathrm{c}$ & $5.46 \mathrm{c}$ & 3.53 \\
& $\mathrm{~S} 3$ & $39.27 \mathrm{a}$ & $28.14 \mathrm{a}$ & $5.20 \mathrm{a}$ & $24.13 \mathrm{a}$ & $12.26 \mathrm{a}$ & 5.04 \\
& & & & & & & \\
\hline T2 & $\mathrm{S} 1$ & $9.90 \mathrm{~d}$ & $6.77 \mathrm{e}$ & $1.22 \mathrm{~d}$ & $5.58 \mathrm{~d}$ & $1.54 \mathrm{e}$ & 1.25 \\
& $\mathrm{~S} 2$ & $23.81 \mathrm{~b}$ & $16.32 \mathrm{c}$ & $2.93 \mathrm{c}$ & 12.60 & $4.12 \mathrm{~d}$ & 2.78 \\
& $\mathrm{~S} 3$ & $36.58 \mathrm{a}$ & $25.69 \mathrm{~b}$ & $4.32 \mathrm{~b}$ & $20.19 \mathrm{~b}$ & $10.34 \mathrm{~b}$ & 3.97 \\
\hline Statistical & & & & & & & \\
Significance & & $* *$ & $* *$ & $* *$ & $* *$ & $* *$ & $\mathrm{NS}$ \\
& & & & & & & \\
Grand Mean & & 24.20 & 16.62 & 2.99 & 13.68 & 6.31 & 3.10 \\
S.E. (S-mean) & & 0.744 & 0.410 & 0.080 & 0.314 & 0.185 & 0.105 \\
\hline
\end{tabular}

1/ Means under each column heading having the same letter (s) are not significantly different at $5 \%$ level (DMRT)

NS - Not significant

** - Highly signigicant at $1 \%$ level 
Table 5

Interaction effects of height levels (L) by segments (S) of sampling areas on the mechanical Properties (static bending (modulus of rupture (MOR), stress at bending (modulus of rupture

(MOR), stress at elastic limit (SEL), and modulus of elastic (MOE); compression perpendicular to grain $(\mathrm{C} / / \mathrm{G})$; compression parallel to grain $(\mathrm{C} \mathrm{G})$; and shear parallel to grain $(\mathrm{S} / / \mathrm{G})$ of coconut wood

\begin{tabular}{|c|c|c|c|c|c|c|c|}
\hline \multicolumn{2}{|c|}{ Sampling Area } & \multicolumn{3}{|c|}{ Static Bending } & \multirow[b]{2}{*}{$\begin{array}{c}\mathrm{C} / / \mathrm{G} \\
(\mathrm{MPa})\end{array}$} & \multirow[b]{2}{*}{$\begin{array}{c}\mathrm{CG} \\
(\mathrm{MPa})\end{array}$} & \multirow[b]{2}{*}{$\begin{array}{l}\mathrm{S} / / \mathrm{G} \\
(\mathrm{MPa})\end{array}$} \\
\hline $\begin{array}{l}\text { Height } \\
\text { (L) }\end{array}$ & $\begin{array}{l}\text { Segment } \\
\text { (S) }\end{array}$ & $\begin{array}{l}\text { MOR } \\
(\mathrm{MPa})\end{array}$ & $\begin{array}{l}\text { SEL } \\
(\mathrm{MPa})\end{array}$ & $\begin{array}{c}\text { MOE } \\
\text { (x1000MPa) }\end{array}$ & & & \\
\hline L1 & $\begin{array}{l}\text { S1 } \\
\text { S2 } \\
\text { S3 }\end{array}$ & $\begin{array}{l}16.19 \\
24.43 \\
48.01\end{array}$ & $\begin{array}{l}10.56 \mathrm{~g} \\
17.57 \mathrm{e} \\
32.97 \mathrm{a}\end{array}$ & $\begin{array}{l}1.89 \\
3.11 \\
5.94\end{array}$ & $\begin{array}{c}8.49 \\
15.21 \\
27.59\end{array}$ & $\begin{array}{c}2.76 \mathrm{def} \\
6.03 \mathrm{~cd} \\
16.29 \mathrm{a}\end{array}$ & $\begin{array}{l}2.38 \\
3.41 \\
5.07\end{array}$ \\
\hline L2 & $\begin{array}{l}\text { S1 } \\
\text { S2 } \\
\text { S3 }\end{array}$ & $\begin{array}{l}13.06 \\
25.06 \\
39.97\end{array}$ & $\begin{array}{l}7.97 \mathrm{gh} \\
16.72 \mathrm{e} \\
28.56 \mathrm{~b}\end{array}$ & $\begin{array}{l}1.49 \\
3.03 \\
4.81\end{array}$ & $\begin{array}{c}6.58 \\
13.74 \\
24.47\end{array}$ & $\begin{array}{c}1.97 \mathrm{ef} \\
5.02 \mathrm{cde} \\
14.47 \mathrm{a}\end{array}$ & $\begin{array}{l}1.96 \\
3.34 \\
4.55\end{array}$ \\
\hline L3 & $\begin{array}{l}\text { S1 } \\
\text { S2 } \\
\text { S3 }\end{array}$ & $\begin{array}{c}9.66 \\
21.56 \\
35.52\end{array}$ & $\begin{array}{c}6.48 \mathrm{hi} \\
14.60 \mathrm{ef} \\
25.64 \mathrm{c}\end{array}$ & $\begin{array}{l}1.21 \\
2.75 \\
4.68\end{array}$ & $\begin{array}{c}5.02 \\
12.36 \\
19.21\end{array}$ & $\begin{array}{c}1.51 \mathrm{ef} \\
4.46 \mathrm{cde} \\
10.77 \mathrm{~b}\end{array}$ & $\begin{array}{l}1.42 \\
2.92 \\
4.40\end{array}$ \\
\hline L4 & $\begin{array}{l}\text { S1 } \\
\text { S2 } \\
\text { S3 }\end{array}$ & $\begin{array}{c}7.32 \\
19.43 \\
28.19\end{array}$ & $\begin{array}{c}4.89 \mathrm{i} \\
13.01 \mathrm{fg} \\
20.49 \mathrm{~d}\end{array}$ & $\begin{array}{l}0.86 \\
2.45 \\
3.61\end{array}$ & $\begin{array}{c}3.93 \\
10.19 \\
17.38\end{array}$ & $\begin{array}{c}1.13 \mathrm{f} \\
3.65 \mathrm{def} \\
7,67 \mathrm{bc}\end{array}$ & $\begin{array}{l}0.83 \\
2.91 \\
3.99\end{array}$ \\
\hline $\begin{array}{l}\text { Statistical } \\
\text { Signigicance }\end{array}$ & & NS & $* *$ & NS & NS & $* *$ & NS \\
\hline $\begin{array}{l}\text { Grand Mean } \\
\text { S.E. (S-mean) }\end{array}$ & & $\begin{array}{l}24.20 \\
1.535 \\
\end{array}$ & $\begin{array}{l}16.62 \\
0.497\end{array}$ & $\begin{array}{r}2.99 \\
0.194 \\
\end{array}$ & $\begin{array}{l}13.68 \\
1.181 \\
\end{array}$ & $\begin{array}{c}6.31 \\
0.596\end{array}$ & $\begin{array}{c}3.10 \\
0.153 \\
\end{array}$ \\
\hline
\end{tabular}

1) means under each column heading having the same (letter(s) are not significantly different at $5 \%$ level (DMRT)

NS - Not significant

** - highly significant at $1 \%$ level 
Table 6

Interation effects of trees $(\mathrm{T})$ by height level (L) by segments (S) of sampling Aeas on mechnical properties (static bending (modulus of rupture (MCR), stress at bending (modulus of rupture (MCR), stress at static limit (SEL), and modulus of elasticity (MOE); compression perpendicular to grain $(\mathrm{C} / / \mathrm{G})$; compression parallel to grain $(\mathrm{C} \mathrm{G})$; and shear parallel to grain $(\mathrm{S} / / \mathrm{G})$ of coconut wood

\begin{tabular}{|c|c|c|c|c|c|c|c|c|}
\hline \multicolumn{3}{|c|}{ Sampling Area } & \multicolumn{3}{|c|}{ Static Bending } & \multirow[b]{2}{*}{$\begin{array}{c}\mathrm{C} / / \mathrm{G} \\
(\mathrm{MPa})\end{array}$} & \multirow[b]{2}{*}{$\begin{array}{c}\mathrm{C} \mathrm{G} \\
(\mathrm{MPa})\end{array}$} & \multirow[b]{2}{*}{$\begin{array}{l}\mathrm{S} / / \mathrm{G} \\
(\mathrm{MPa})\end{array}$} \\
\hline $\begin{array}{c}\text { Trees } \\
(\mathrm{T})\end{array}$ & $\begin{array}{l}\text { Height } \\
\text { (L) }\end{array}$ & $\begin{array}{l}\text { Segment } \\
\text { (S) }\end{array}$ & $\begin{array}{l}\text { MCR } \\
(\mathrm{MPa})\end{array}$ & $\begin{array}{c}\text { SEL } \\
(\mathrm{MPa})\end{array}$ & $\begin{array}{c}\mathrm{MOE} \\
(\mathrm{x} 1000 \mathrm{MPa} \\
)\end{array}$ & & & \\
\hline T1 & L1 & $\begin{array}{l}\text { S1 } \\
\text { S2 } \\
\text { S3 }\end{array}$ & $\begin{array}{l}18.05 \\
24.75 \\
52.18\end{array}$ & $\begin{array}{l}11.15 \\
16.03 \\
34.40\end{array}$ & $\begin{array}{c}1.96 \mathrm{ij} \\
2.79 \mathrm{fgh} \\
6.64 \mathrm{a}\end{array}$ & $\begin{array}{l}9.161 \mathrm{~m} \\
15.42 \mathrm{~h} \\
31.64 \mathrm{a}\end{array}$ & $\begin{array}{c}2.91 \mathrm{jklm} \\
6.64 \mathrm{fg} \\
18.85 \mathrm{a}\end{array}$ & $\begin{array}{c}3.08 \mathrm{hij} \\
3.81 \mathrm{fg} \\
5.71\end{array}$ \\
\hline & L2 & $\begin{array}{l}\text { S1 } \\
\text { S2 } \\
\text { S3 }\end{array}$ & $\begin{array}{l}15.82 \\
25.38 \\
41.62\end{array}$ & $\begin{array}{c}9.13 \\
15.93 \\
30.26\end{array}$ & $\begin{array}{l}1.75 \mathrm{jk} \\
3.08 \mathrm{ef} \\
5.25 \mathrm{~b}\end{array}$ & $\begin{array}{c}7.36 \mathrm{mn} \\
14.27 \mathrm{hi} \\
28 / 47 \mathrm{~b}\end{array}$ & $\begin{array}{c}2.53 \mathrm{klm} \\
5.77 \mathrm{fgh} \\
17.58 \mathrm{~b}\end{array}$ & $\begin{array}{l}2.70 \mathrm{ij} \\
3.69 \mathrm{fg} \\
4.94 \mathrm{~b}\end{array}$ \\
\hline & L3 & $\begin{array}{l}\text { S1 } \\
\text { S2 } \\
\text { S3 }\end{array}$ & $\begin{array}{l}10.72 \\
19.96 \\
36.31\end{array}$ & $\begin{array}{c}7.33 \\
13.80 \\
26.86\end{array}$ & $\begin{array}{c}1.41 \mathrm{jkl} \\
2.60 \mathrm{fgh} \\
5.11 \mathrm{~b}\end{array}$ & $\begin{array}{c}5.24 \mathrm{o} \\
12.67 \mathrm{ij} \\
19.43 \mathrm{de}\end{array}$ & $\begin{array}{l}1.851 \mathrm{~m} \\
5.24 \mathrm{hi} \\
12.32 \mathrm{~d}\end{array}$ & $\begin{array}{l}1.64 \mathrm{k} \\
3.34 \mathrm{gh} \\
4.81 \mathrm{bc}\end{array}$ \\
\hline & L4 & $\begin{array}{l}\text { S1 } \\
\text { S2 } \\
\text { S3 }\end{array}$ & $\begin{array}{c}8.28 \\
19.64 \\
26.97\end{array}$ & $\begin{array}{c}5.10 \\
12.74 \\
21.02\end{array}$ & $\begin{array}{c}0.891 \mathrm{~m} \\
2.50 \mathrm{gh} \\
3.80 \mathrm{~d}\end{array}$ & $\begin{array}{l}3.98 \mathrm{op} \\
10.25 \mathrm{k} \\
17.20 \mathrm{~g}\end{array}$ & $\begin{array}{c}1.31 \mathrm{mn} \\
4.20 \mathrm{ij} \\
9.30 \mathrm{e}\end{array}$ & $\begin{array}{c}0.781 \\
3.26 \mathrm{ghi} \\
4.69 \mathrm{bcd}\end{array}$ \\
\hline $\mathrm{T} 2$ & L1 & $\begin{array}{l}\text { S1 } \\
\text { S2 } \\
\text { S3 } \\
\end{array}$ & $\begin{array}{l}14.33 \\
28.14 \\
43.65 \\
\end{array}$ & $\begin{array}{c}9.98 \\
19.11 \\
31.53 \\
\end{array}$ & $\begin{array}{l}1.82 \mathrm{j} \\
3.43 \mathrm{e} \\
5.23 \mathrm{~b} \\
\end{array}$ & $\begin{array}{l}7.83 \mathrm{~m} \\
15.01 \mathrm{~h} \\
23.74 \mathrm{c} \\
\end{array}$ & $\begin{array}{c}2.61 \mathrm{klm} \\
5.42 \mathrm{ghi} \\
13.73 \mathrm{c}\end{array}$ & $\begin{array}{c}1.68 \mathrm{k} \\
3.01 \mathrm{hij} \\
4.42 \mathrm{cde}\end{array}$ \\
\hline & $\mathrm{L} 2$ & $\begin{array}{l}\text { S1 } \\
\text { S2 } \\
\text { S3 }\end{array}$ & $\begin{array}{l}10.30 \\
24.74 \\
38.33\end{array}$ & $\begin{array}{c}6.80 \\
17.52 \\
26.86\end{array}$ & $\begin{array}{c}1.23 \mathrm{klm} \\
2.98 \mathrm{efg} \\
4.36 \mathrm{c}\end{array}$ & $\begin{array}{l}5.79 \mathrm{no} \\
13.21 \mathrm{jk} \\
20.48 \mathrm{~d}\end{array}$ & $\begin{array}{l}1.41 \mathrm{mn} \\
4.26 \mathrm{ij} \\
11.35 \mathrm{~d}\end{array}$ & $\begin{array}{l}1.22 \mathrm{kl} \\
2.98 \mathrm{hij} \\
4.16 \mathrm{def}\end{array}$ \\
\hline & L3 & $\begin{array}{l}\text { S1 } \\
\text { S2 } \\
\text { S3 }\end{array}$ & $\begin{array}{c}8.60 \\
23.15 \\
34.72\end{array}$ & $\begin{array}{c}5.62 \\
15.40 \\
24.42\end{array}$ & $\begin{array}{l}1.001 \mathrm{~m} \\
2.91 \mathrm{fg} \\
4.25 \mathrm{~cd}\end{array}$ & $\begin{array}{l}4.79 \mathrm{cp} \\
12.04 \mathrm{jk} \\
18.99 \mathrm{ef}\end{array}$ & $\begin{array}{c}1.17 \mathrm{mn} \\
3.68 \mathrm{jk} \\
0.23 \mathrm{e}\end{array}$ & $\begin{array}{l}1.20 \mathrm{kl} \\
2.56 \mathrm{j} \\
3.99 \mathrm{ef}\end{array}$ \\
\hline & L4 & $\begin{array}{l}\text { S1 } \\
\text { S2 } \\
\text { S3 } \\
\end{array}$ & $\begin{array}{c}6.37 \\
19.22 \\
29.41 \\
\end{array}$ & $\begin{array}{c}4.67 \\
13.27 \\
19.96 \\
\end{array}$ & $\begin{array}{l}0.83 \mathrm{~m} \\
2.39 \mathrm{hi} \\
3.42 \mathrm{e} \\
\end{array}$ & $\begin{array}{c}3.89 \mathrm{p} \\
10.131 \\
17.56 \mathrm{fg} \\
\end{array}$ & $\begin{array}{c}0.96 \mathrm{n} \\
3.10 \mathrm{jkl} \\
7.03 \mathrm{f}\end{array}$ & $\begin{array}{c}0.891 \\
2.56 \mathrm{j} \\
3.30 \mathrm{ghi}\end{array}$ \\
\hline $\begin{array}{l}\text { Statistical } \\
\text { Significance }\end{array}$ & & & NS & NS & $*$ & $* *$ & $* *$ & $*$ \\
\hline $\begin{array}{l}\text { Grand Mean } \\
\text { S.E. (S-mean) } \\
\text { C.V.residual(\% } \\
\text { ) }\end{array}$ & & & $\begin{array}{c}24.20 \\
0.935 \\
10.7\end{array}$ & $\begin{array}{c}16.62 \\
0.633 \\
8.5\end{array}$ & $\begin{array}{c}2.99 \\
0.101 \\
9.3\end{array}$ & $\begin{array}{c}13.68 \\
0.344 \\
7.9\end{array}$ & $\begin{array}{c}6.31 \\
0.270 \\
10.2\end{array}$ & $\begin{array}{c}3.10 \\
0.129 \\
11.8\end{array}$ \\
\hline
\end{tabular}

1) Means under each column heading having the same letter (s) are not significantly different at $5 \%$ level (DMRT)

NS - Not significant

* - significant at $5 \%$ level

** - highly significant at $1 \%$ level 